\title{
Quantitative Pharmacological Analysis of 2-125|-Iodomelatonin Binding Sites in Discrete Areas of the Chicken Brain
}

\author{
J. A. Siuciak, ${ }^{1}$ D. N. Krause, ${ }^{2}$ and M. L. Dubocovich ${ }^{1}$ \\ 'Department of Pharmacology, Northwestern University Medical School, Chicago, Illinois 60611 and 'Department of \\ Pharmacology, College of Medicine, University of California at Irvine, Irvine, California 92717
}

We have localized and characterized 2-125|-iodomelatonin binding sites in the chicken brain using in vitro quantitative autoradiography. Binding sites were widely distributed throughout the chicken brain, predominantly in regions associated with the visual system. The specific binding of 2-125-iodomelatonin to discrete chicken brain areas was found to be saturable, reversible, and of high affinity. The specific binding of 2-125/-iodomelatonin (75 pM) was quantitated for 40 identifiable brain regions. Eight brain regions were chosen for binding characterization and pharmacological analysis: optic tectum, Edinger-Westphal nucleus, oculomotor nucleus, nucleus rotundus, ventral supraoptic decussation, ventrolateral geniculate nucleus, neostriatum, and ectostriatum. These regions showed no rostral-caudal gradient in 2-125|iodomelatonin specific binding, and saturation analysis revealed a single class of high-affinity sites with $K_{b}$ values in the range of 33-48 pM and receptor site density $\left(B_{\max }\right)$ ranging from 31 to $58 \mathrm{fmol} / \mathrm{mg}$ protein. Competition experiments carried out with various indoles revealed a similar order of pharmacological affinities in these areas: melatonin > 6-chloromelatonin $>$ methoxyluzindole $>\mathrm{N}$-acetylserotonin $>$ luzindole $\gg 5-\mathrm{HT}>5$-methoxytryptamine. The affinity constants determined by quantitative autoradiography for these compounds to compete for 2-125/-iodomelatonin binding in the optic tectum correlated well with the affinities in chicken brain membranes at $25^{\circ} \mathrm{C}(r=0.966$; slope $=0.845$; $n=7)$ and $0^{\circ} \mathrm{C}(r=0.946$; slope $=0.379 ; n=7)$, chicken retinal membranes $(r=0.973$; slope $=0.759 ; n=7)$, and the potency or affinity of these compounds to affect the calciumdependent release of ${ }^{3} \mathrm{H}$-dopamine from the rabbit retina ( $r$ $=0.902$; slope $=0.506 ; n=6$ ). We conclude that the highaffinity sites labeled by 2 -125|-iodomelatonin in various chicken brain areas have identical binding and pharmacological characteristics to the ML-1 melatonin binding site previously described in chicken brain and retinal membranes and to

\footnotetext{
Received Nov. 13, 1990; revised Mar. 25, 1991; accepted Apr. 22, 1991.

We would like to thank Dr. Francis M. Leslie for assistance with the image analysis system. This work was supported by U.S. Public Health Service Grant MH42922 to M.L.D. and postdoctoral fellowships from Training Grant NS-07140 and National Research Service Award MH09997 to J.A.S. Preliminary reports of these results were presented at the 19th Annual Meeting of the Society for Neuroscience in Phoenix, AZ, the XIth International Congress of Pharmacology, Amsterdam, The Netherlands, and the 20th Annual Meeting of the Society for Neuroscience in St. Louis, MO

Correspondence should be addressed to Dr. M. L. Dubocovich, Department of Pharmacology, Northwestern University Medical School, 303 East Chicago Avenue, Chicago, IL 60611.

Copyright (C) 1991 Society for Neuroscience $0270-6474 / 91 / 112855-10 \$ 03.00 / 0$
}

the ML-1 melatonin receptor modulating dopamine release from the retina. In the chicken brain, the ML-1 receptor site may mediate functional responses regulated by melatonin.

The avian pineal gland, through the secretion of its primary neurohormone melatonin (MEL; $N$-acetyl-5-methoxytryptamine), appears to be involved in the regulation of circadian locomotor rhythms (Gaston and Menaker, 1968; Menaker and Zimmermann, 1976; Turek et al., 1976; Ebihara and Kawamura, 1981; Simpson and Follet, 1981; Ebihara et al., 1984; Oshima et al., 1989), body temperature (Oshima et al., 1989), feeding behavior (Yamada et al., 1988), sleep-like behavior (Barchas et al., 1967), photoperiodic regulation of reproduction (Johnson and van Tichoven, 1984; Liou ct al., 1987; Ohta ct al., 1989), and 5-HT levels in different brain regions (Cassone et al., 1986). MEL levels in pineal, serum, brain, and retina fluctuate diurnally, with higher levels during the dark phase (Pang et al., 1974, 1977, 1983; Cassone and Menaker, 1984; Vakkuri et al., 1985). Furthermore, MEL is taken up from the circulation and concentrated in the brain, particularly within the hypothalamus, thalamus, and pons/midbrain, which may be major sites of action of this hormone (Pang et al., 1974; Ralph, 1981; Cassone and Menaker, 1984; Cassone et al., 1986).

Recently, 2-125I-iodomelatonin has been used to study MEL receptor sites (Vakkuri et al., 1984; Dubocovich and Takahashi, 1987). Specific 2-125I-iodomelatonin binding sites have been demonstrated in the chicken brain using both membrane preparations (Dubocovich et al., 1989, 1990; Rivkees et al., 1989) and autoradiographic localization (Rivkees et al., 1989; Siuciak and Dubocovich, 1989; Dubocovich et al., 1990; Stehle, 1990). In contrast to previous autoradiographic studies using rodents, where MEL binding sites were found to be localized in only a few discrete areas such as the suprachiasmatic nucleus (SCN), the thalamic paraventricular nucleus (PVN), and the median eminence/pars tuberalis (ME/PT) (Duncan et al., 1989; Weaver et al., 1989; Siuciak et al., 1990), binding was widely distributed throughout the entire chicken brain.

2-125 I-iodomelatonin has been shown to label two pharmacologically distinct sites, ML-1 and ML-2 (Dubocovich, 1988a). The ML-1 site was originally characterized in the chicken and rabbit retina (Dubocovich, 1983, 1985, 1988a; Dubocovich and Takahashi, 1987), where it functions to inhibit ${ }^{3} \mathrm{H}$-dopamine release (Dubocovich, 1983, 1985). Sites with similar pharmacological characteristics have since been found in the chicken brain (Dubocovich et al., 1989, 1990), rat SCN and median eminence (Vanecek et al., 1987; Laitinen and Saavedra, 1990; Laitinen et al., 1990), and mouse SCN and PVN (Fang et al., 


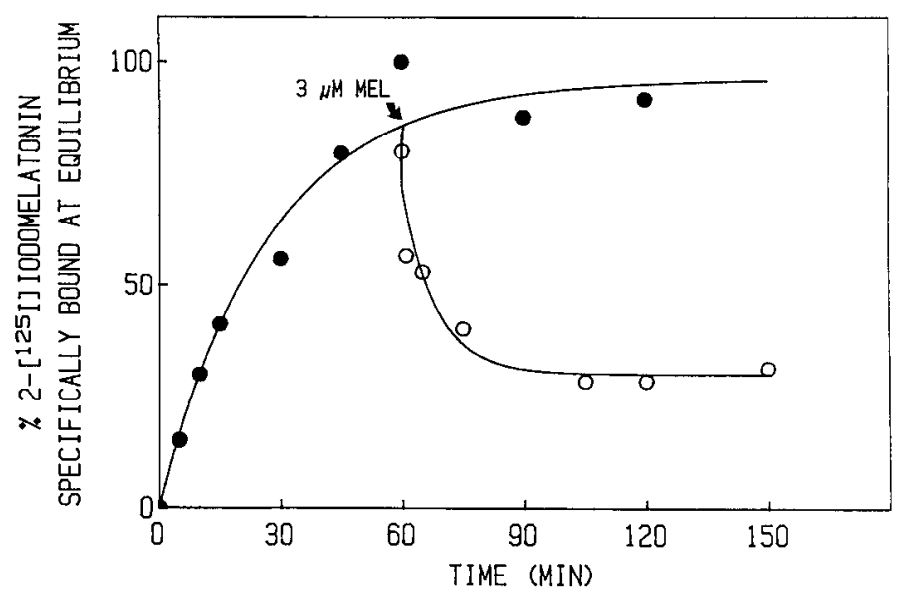

Figure 1. Time course of $2-{ }^{125}$ I-iodomelatonin binding in the OT from chicken brain slices using quantitative autoradiography. Coronal chicken brain sections, $20 \mu \mathrm{m}$ thick, through the optic lobes were incubated with 75 pM 2-125I-iodomelatonin. 2-125I-iodomelatonin binding (open circles) was brought to steady state $(60 \mathrm{~min})$ before the addition of 3 $\mu \mathrm{M}$ MEL to all samples (solid circles). At the times indicated, slidemounted sections were removed and washed as described in Materials and Methods. Values shown are from a representative experiment, with points representing the mean of triplicate determinations (three sections per slide)

1990). Lower-affinity melatonin binding sites (ML-2) have been found in hamster brain membranes (Niles et al., 1987; Duncan et al., 1988, 1989). The most striking pharmacological difference between these two binding sites is the equal potency of $\mathrm{MEL}$ and $N$-acetylserotonin (NAS) in competing for 2-125I-iodomelatonin binding in hamster brain membranes (Duncan et al., 1988, 1989), in contrast to the ML- 1 receptor, where MEL exhibits a much greater potency than NAS (Dubocovich 1983, 1985, 1988a; Dubocovich and Takahashi, 1987).

The aim of this study was to examine the distribution and the binding and pharmacological characteristics of $2-{ }^{125} \mathrm{I}$-iodomelatonin binding sites in discrete areas of the adult chicken brain using quantitative autoradiography. In the chicken brain, 2-125I-iodomelatonin labels a high-affinity site with the binding and pharmacological characteristics of the ML-1 MEL receptor previously described in chicken brain and retinal membranes. Knowledge of the distribution and pharmacological characteristics of $2-{ }^{125} \mathrm{I}$-iodomelatonin binding sites in the chicken brain is important for understanding the effects of MEL on behavioral, reproductive, and neurochemical functions.

\section{Materials and Methods}

Chemicals and radioligand. 2-125I-iodomelatonin was prepared using a modification of the method of Vakkuri et al. (1984). This radioligand had a high specific activity $(1800-2000 \mathrm{Ci} / \mathrm{mmol})$ and was stable for at least $60 \mathrm{~d}$. Drugs were obtained from Sigma Chemical Company unless otherwise stated. 6-Chloromelatonin (CLM) was donated by Dr. J. A Clemens (Eli Lilly Laboratories, Indianapolis, IN). Luzindole (LUZ; 2-benzyl- $N$-acetyltryptamine, $\mathrm{N}$-0774) and 5-methoxyluzindole (MLUZ; N-0745) were donated by Dr. J. Peck [Whitby Research (formerly Nelson Research), Irvine, CA].

Autoradiography. Whole brains from 5-6 week-old male and female chickens (Gallus domesticus, white leghorn) were dissected and frozen in 2-methylbutane and stored at $-70^{\circ} \mathrm{C}$. Chickens were obtained from the slaughterhouse and killed by decapitation between 1100 and 1300 $\mathrm{hr}$. Serial coronal brain sections $(20 \mu \mathrm{m})$ were cut on a cryostat $\left(-15^{\circ} \mathrm{C}\right)$ and thaw mounted onto gelatin-coated slides. Three alternate sets of sections were generated for the determination of total binding, nonspecific binding, and histological staining. After air drying for $10 \mathrm{~min}$, slides were stored at $-70^{\circ} \mathrm{C}$ until processing for no more than 1 week. Slidemounted sections (three per slide) were allowed to air dry for $15 \mathrm{~min}$,

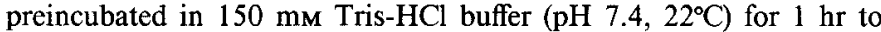
remove endogenous ligand, and then incubated with appropriate concentrations of $2-{ }^{125} \mathrm{I}$-iodomelatonin $(0.1 \mathrm{pm}$ to $1 \mathrm{~nm})$ in Tris- $\mathrm{HCl}$ buffer with (nonspecific binding) or without (total binding) $3 \mu \mathrm{M}$ melatonin for $1 \mathrm{hr}$, with the exception of kinetic studies, for which the incubation time varied. For competition studies, slides containing three adjacent serial sections were incubated with 75 pM $2{ }^{125}$ I-iodomelatonin in the absence or presence of various concentrations of drugs ( $1 \mathrm{pM}$ to $1 \mathrm{mM}$ ). Slides were rinsed in ice-cold Tris- $\mathrm{HCl}$ buffer $(3 \times 5 \mathrm{~min}$ each) followed by a rapid rinse in ice-cold distilled water to remove buffer salts. Labeled sections were apposed to Kodak SB5 $\mathrm{x}$-ray film for 3-7 d. The film was developed using Kodak D19 developer $\left(4^{\circ} \mathrm{C}\right)$. Tissue sections were stained with thionin, and these were used in conjunction with the atlas of Kuenzel and Masson (1989).

Using a computer-based image analysis system (Imaging Resources Inc., St. Catharines, Ontario, Canada), the optical densities of autoradiograms were measured. ${ }^{14} \mathrm{C}$ standards (ARC Inc.) were calibrated for use with ${ }^{125}$ I using the method of Miller and Zahniser (1987). For each brain region, the mean density readings from three sections mounted on the same slide were converted into the amount of radioligand bound using the standard reference curve. The protein content in tissue sections was determined from tissue equivalents supplied by the manufacturer of the ${ }^{14} \mathrm{C}$ standards. The value for nonspecific binding, defined as the binding of $2{ }^{125}$ I-iodomelatonin not displaced by $3 \mu \mathrm{M}$ melatonin, was subtracted from that for total binding to produce the value for specific binding in each region. $K_{i}$ values from competition experiments were calculated using the method of Cheng and Prusoff (1973), and curve fitting was done using the GRAPHPAD program (The Institute for Scientific Information, Philadelphia, PA).

\section{Results}

\section{Incubation conditions}

The time course of binding of 75 pM $2-^{-125} \mathrm{I}$-iodomelatonin to tissue sections is shown in Figure 1 . The binding of $2-{ }^{125} \mathrm{I}$-iodomelatonin was rapid and reversible. At $22^{\circ} \mathrm{C}, 45 \mathrm{~min}$ was required to reach equilibrium, and binding remained stable for up to $2 \mathrm{hr}$. The association rate constant $\left(k_{1}\right)$ from the optic tectum determined from the pseudo-first-order equation was $33.9 \times 10^{7} \mathbf{M}^{-1}$. Dissociation of the bound complex was initiated after $60 \mathrm{~min}$ of incubation with the addition of excess competing ligand ( $3 \mu \mathrm{M} \mathrm{MEL)}$. The rate constant for dissociation $\left(k_{-1}\right)$ from the optic tectum was $0.01439 \mathrm{~min}^{-1}$. The kinetic dissociation constant $\left(K_{d}\right)$ for $2-^{125} \mathrm{I}$-iodomelatonin in the optic tectum calculated from the ratio $k_{-1}: k_{1}$ was $41.06 \pm 3.92$ pM $(n=4)$.

\section{Localization}

The distribution of 2-125I-iodomelatonin binding sites in the chicken brain is shown in Figure 2. 2-125I-Iodomelatonin binding sites were widely distributed throughout the chicken brain predominantly in regions associated with the visual system. A list of these areas and their abbreviations are shown in Table 1. The specific binding of $2-^{125} \mathrm{I}$-iodomelatonin (75 pM) in different brain areas showed an uneven distribution (Table 1). The highest density of 2-125 I-iodomelatonin binding sites was found in the OT, T, and R ( $>30 \mathrm{fmol} / \mathrm{mg}$ protein) as well as in the $\mathrm{DSV}$ and the $\mathrm{GLV}(>20 \mathrm{fmol} / \mathrm{mg}$ protein).

In order to assess whether $2{ }^{-125} \mathrm{I}$-iodomelatonin binding in specific brain areas displayed any rostral-caudal gradient, two entire brains were sectioned and incubated with 75 pM 2-125 Iiodomelatonin. Figure 3 shows the rostral-caudal distribution of specific binding of 2-125 I-iodomelatonin throughout selected areas of the chicken brain, demonstrating that binding was uniform from one section to the next in the OT, R, DSV, EW, GLV, OM, NI, and E, areas that were used in further saturation and pharmacological experiments. 

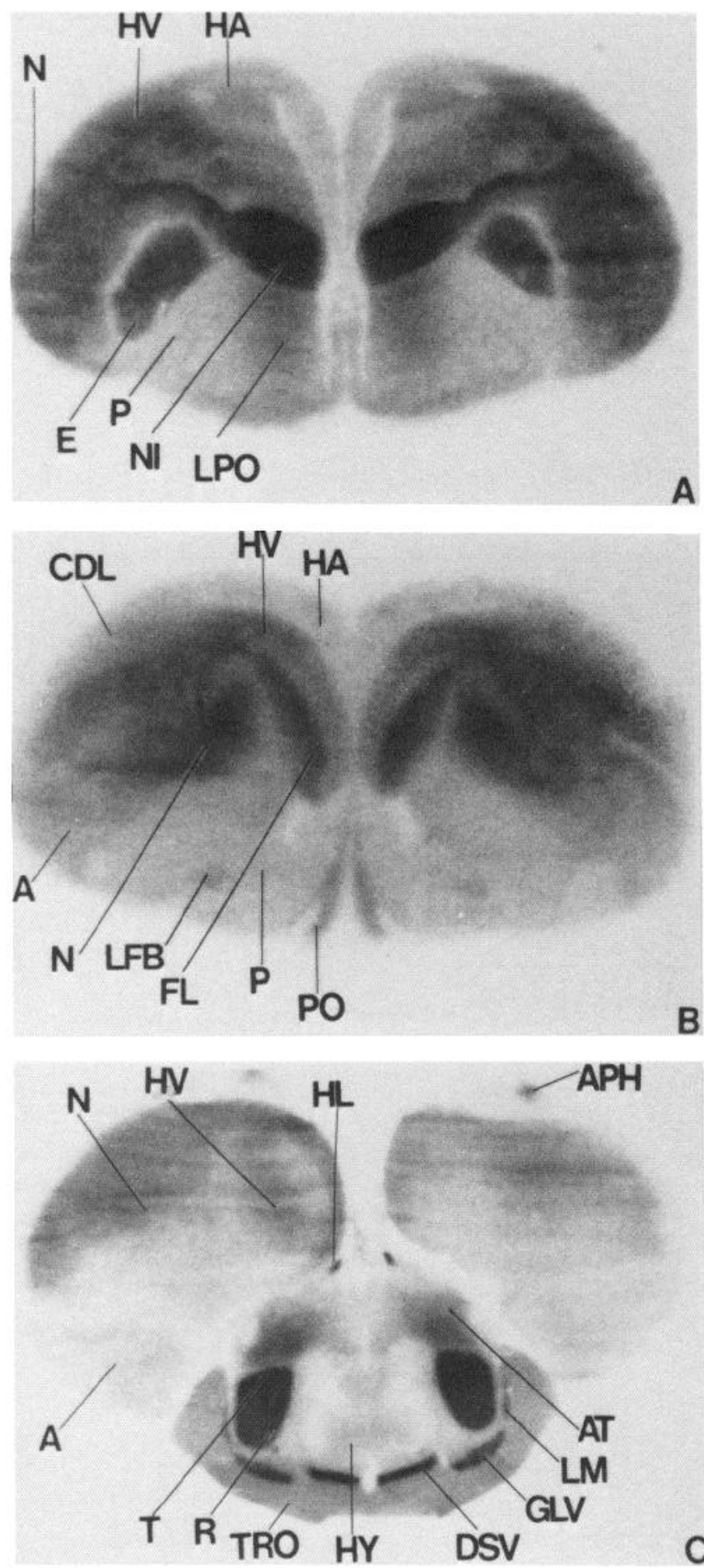

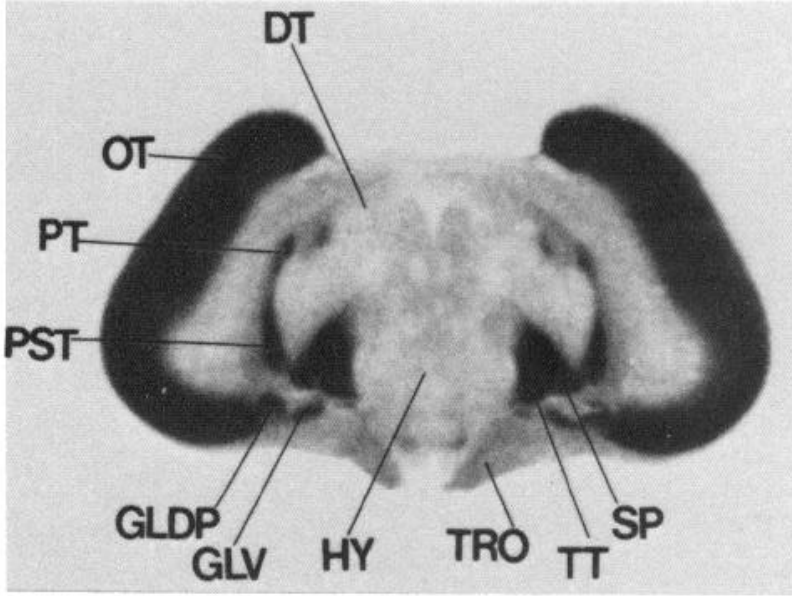

D

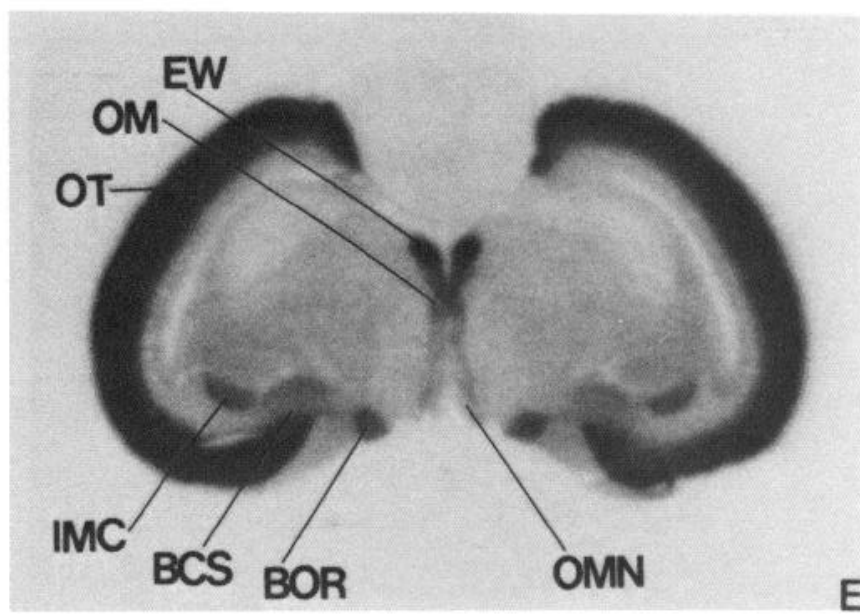

E

Figure 2. Autoradiograms of 2-125I-iodomelatonin binding at five selected coronal levels of the chicken brain. A list of the areas and their abbreviations are given in Table 1. Total binding is shown in $A-E$ and corresponds roughly to plates A $10.0(A)$, A $8.8(B)$, A $6.4(C)$, A $5.0(D)$, and A $3.4(E)$ from the atlas of Kuenzel and Masson (1989). $F$ shows a representative autoradiogram of nonspecific binding defined with $3 \mu \mathrm{M}$ MEL.

\section{Saturation studies}

Scatchard analysis of saturation binding data was carried out in the following areas: OT, EW, OM, R, DSV, GLV, NI, and E using concentrations of 2-125 I-iodomelatonin ranging from 0.1 to 1000 pM. Initial saturation experiments using radioligand concentrations extending from 12.5 to 1000 pM revealed only one high-affinity site; therefore, future experiments were done using smaller concentration ranges. The $K_{D}$ and $B_{\max }$ values for the various areas examined are shown in Table 2 . A representative densitometric analysis of saturation binding from one experiment in the OT is shown in Figure 4. Specific binding of 2-125I-iodomelatonin (0.1-200 pM) to chicken brain OT increased linearly with concentration of the radioligand from 0.1 


\begin{tabular}{|c|c|c|c|}
\hline Brain area & Abbreviation & $\mathrm{fmol} / \mathrm{mg}$ protein & $(n)$ \\
\hline \multicolumn{4}{|l|}{ Mesencephalic areas } \\
\hline Optic tectum ${ }^{a}$ & OT & $37.56+1.84$ & (22) \\
\hline Edinger-Westphal nuclei ${ }^{b}$ & EW & $19.01 \pm 1.87$ & (16) \\
\hline Oculomotor nuclei ${ }^{b}$ & OM & $13.03 \pm 0.81$ & (16) \\
\hline Brachium superior colliculus ${ }^{b}$ & $\mathrm{BCS}$ & $12.58 \pm 0.58$ & $(10)$ \\
\hline Basal optic root nuclei ${ }^{a}$ & BOR & $12.26 \pm 1.01$ & (14) \\
\hline Lentiform mesencephalic nucleus & LM & $11.53 \pm 1.01$ & (11) \\
\hline Magnocellular isthmi nuclei ${ }^{b}$ & IMC & $10.53 \pm 0.65$ & (14) \\
\hline Parvocellular isthmi nuclei ${ }^{b}$ & IPC & $6.13 \pm 0.41$ & (14) \\
\hline Oculomotor nerve & $\mathrm{OMN}$ & $6.04 \pm 0.42$ & (12) \\
\hline Trochlear nerve nucleus & nIV & $4.94 \pm 0.28$ & (6) \\
\hline \multicolumn{4}{|l|}{ Diencephalic areas } \\
\hline Nucleus triangularis ${ }^{b}$ & $\mathrm{~T}$ & $56.49 \pm 5.63$ & $(10)$ \\
\hline Tectothalamic tract & $\mathrm{TT}$ & $39.80 \pm 3.04$ & (14) \\
\hline Nucleus rotundus $s^{b}$ & $\mathrm{R}$ & $37.52 \pm 1.85$ & (12) \\
\hline Ventral supraoptic decussation ${ }^{a}$ & DSV & $25.24 \perp 2.02$ & (14) \\
\hline Ventrolateral geniculate nucleus ${ }^{a}$ & GLV & $18.94 \pm 1.01$ & (20) \\
\hline Dorsolateral geniculate nucleus ${ }^{a}$ & GLDP & $13.21 \pm 0.35$ & (8) \\
\hline Pretectal nucleus ${ }^{b}$ & PT & $15.75 \pm 0.82$ & (8) \\
\hline Subpretectal nucleus ${ }^{b}$ & SP & $15.31 \pm 0.63$ & (16) \\
\hline Pretectal-subpretectal tract & PST & $14.91 \pm 0.81$ & (12) \\
\hline Anterior thalamic area ${ }^{a}$ & $\mathrm{AT}$ & $12.53 \pm 0.33$ & (6) \\
\hline Lateral habenular nucleus & HL & $11.32 \pm 0.87$ & (6) \\
\hline Optic tract & TRO & $6.46 \pm 0.26$ & (16) \\
\hline Optic chiasm & $\mathrm{OC}$ & $6.46 \pm 0.28$ & (6) \\
\hline Lateral hypothalamic area ${ }^{a}$ & $\mathrm{HY}$ & $5.48 \pm 0.37$ & (20) \\
\hline Dorsolateral thalamic area ${ }^{a}$ & DT & $4.57 \pm 0.15$ & (20) \\
\hline \multicolumn{4}{|l|}{ Telencephalic sites } \\
\hline Neostriatum intermedium & NI & $11.51 \pm 0.52$ & (20) \\
\hline Ectostriatum & $\mathrm{E}$ & $8.56 \pm 0.36$ & (20) \\
\hline Field $\mathbf{L}$ & FL & $7.90 \pm 0.33$ & (10) \\
\hline Area parahippocampus & $\mathrm{APH}$ & $7.33 \perp 0.26$ & (14) \\
\hline Neostriatum & $\mathrm{N}$ & $6.95 \pm 0.48$ & (20) \\
\hline Hyperstriatum ventrale & HV & $5.47 \pm 0.22$ & (20) \\
\hline Neostriatum caudale & $\mathrm{NC}$ & $5.23 \pm 0.20$ & (10) \\
\hline Dorsolateral corticoid area & $\mathrm{CDL}$ & $4.53 \pm 0.31$ & (12) \\
\hline Lateral forebrain bundle & LFB & $4.06 \pm 0.18$ & (10) \\
\hline Paraolfactory lobe & LPO & $3.88 \pm 0.12$ & (20) \\
\hline Archistriatum & A & $3.78 \pm 0.24$ & (12) \\
\hline Hyperstriatum accessorium & HA & $3.69 \pm 0.11$ & (20) \\
\hline Olfactory tubercle & TO & $3.57 \pm 0.07$ & (4) \\
\hline Paleostriatum & $\mathbf{P}$ & $3.35 \pm 0.07$ & $(12)$ \\
\hline Preoptic area & PO & $3.23 \pm 0.09$ & (10) \\
\hline
\end{tabular}

Values for density of 2-125I-iodomelatonin binding (75 pM) are shown as mean \pm SEM of independent determinations performed in triplicate (three sections per slide). The number of independent determinations $(n)$ is shown in parentheses. ${ }^{a}$ Retinorecipient areas (Ehrlich and Mark, 1984).

$b$ Thalamic and mesencephalic relay nuclei.

to $75 \mathrm{pm}$ and reached saturation at $100 \mathrm{pm}$. Similar results were found in all areas examined over the entire 2-125I-iodomelatonin concentration range used. Scatchard plots were linear, indicating a single class of high-affinity binding sites (33-48 pм). In the OT, the apparent dissociation constants for 2-125 I-iodomelatonin derived from kinetic analysis $\left(K_{d}=41.06 \pm 3.92 \mathrm{pM} ; n=4\right)$ and saturation experiments $\left(K_{d}=43.49 \pm 9.18 \mathrm{pM} ; n=8\right)$ are in agreement.

\section{Pharmacological properties}

Inhibition of 2-125I-iodomelatonin binding (75 pM) to chicken brain sections was determined for eight concentrations of one of the following drugs: MEL, CLM, NAS, 5-methoxytryptamine (5-MT), LUZ, 5-methoxyluzindole (MLUZ), and 5-HT. A list of $K_{i}$ values (mean \pm SEM) for all drugs and areas examined is shown in Table 3 . A representative analysis of the inhibition of 


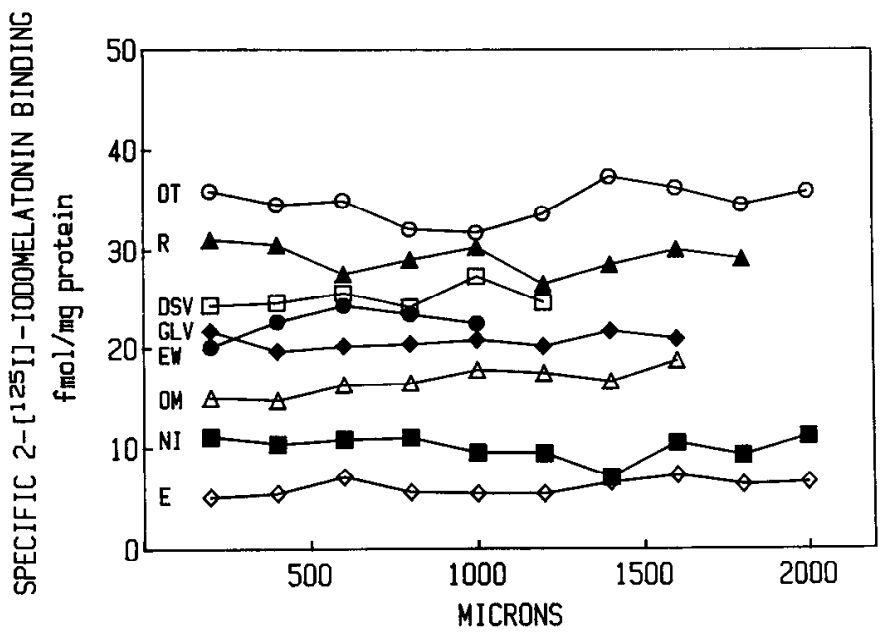

Figure 3. Rostrocaudal analysis of 2-125 I-iodomelatonin binding throughout the OT, R, DSV, GLV, EW, OM, NI, and E. Sequential coronal $20 \mu \mathrm{m}$ sections throughout the brain were incubated with 75 pM 2-125I-iodomelatonin as described in Materials and Methods. The $\mathrm{x}$-axis indicates the distance in microns through all sections in which the indicated brain region appears. Values shown are from a representative experiment.

binding of $2-125 \mathrm{I}$-iodomelatonin in the OT is shown in Figure 5 . The apparent dissociation constants for 2-125 I-iodomelatonin in the OT derived from competition experiments (MEL, $K_{i}=$ $44.92 \mathrm{pM} \pm 4.21 ; n=8$ ) are in agreement with those derived from kinetic analysis and saturation experiments. In the tectum, MEL and CLM were potent competitors of 2-125 I-iodumelatonin binding $\left(K_{i}=44.92 \pm 4.21\right.$ pM and $215.52 \pm 7.24$ pM, respectively), while MLUZ and NAS were less effective ( $K_{f}=1.04 \pm$ $0.04 \mathrm{~nm}$ and $294.69 \pm 33.48 \mathrm{nM}$, respectively). The $K_{i}$ values for LUZ, the competitive MEL receptor antagonist (Dubocovich, $1988 \mathrm{~b}$ ), were also in the nanomolar range (745.15 \pm 129.45 nM). 5-HT and 5-MT were far less potent in displacing 2-125 $\mathrm{I}$ - iodomelatonin in the chicken brain $\left(K_{i}=19.97 \pm 3.38 \mu \mathrm{M}\right.$ and $459.69 \pm 3.48 \mu \mathrm{M}$, respectively). All areas displayed an identical order of pharmacological affinity: MEL $>$ CLM $>$ MLUZ > NAS $>$ LUZ $\gg 5$-HT $>$ 5-MT (see Table 3).

Correlation between the affinities of various indoles to inhibit $2-{ }^{125}$ I-iodomelatonin binding and functional responses in the brain and retina

The pharmacological characteristics of the $2-{ }^{125}$ I-iodomelatonin binding sites in discrete areas of the chicken brain using quantitative autoradiographic analysis and those found in chicken brain and retinal membranes (Dubocovich and Takahashi, 1987; Dubocovich et al., 1989; K. Chung and M. L. Dubocovich, unpublished observations) are very similar. Previous studies have shown that the potency of MEL and related agonists to inhibit the calcium-dependent release of ${ }^{3} \mathrm{H}$-dopamine from rabbit and chicken retina correlates with the affinities of the same compounds to compete for 2-125 I-iodomelatonin binding sites in chicken retinal membranes (Dubocovich, 1985; Dubocovich and Takahashi, 1987). A high correlation between the affinity of MEL and related compounds to compete for 2-125I-iodomelatonin binding sites in the chicken brain and chicken retinal membranes has also been shown (Dubocovich et al., 1989). Figure $6 A$ shows the correlation between the affinities of MEL and related compounds to inhibit the binding of $2-{ }^{125}$ I-iodomelatonin in the OT (present results; Table 3 ) and in chicken brain membranes $\left(25^{\circ} \mathrm{C}\right.$; Chung and Dubocovich, unpublished observations). The pharmacological profile of the $2-{ }^{125}$ I-iodomelatonin binding site in the OT corresponds closely to that in chicken brain membranes $\left(25^{\circ} \mathrm{C} ; r=0.966\right.$; slope $=0.845 ; n=$ 7 ). These results suggest that $2-{ }^{125} \mathrm{I}$-iodomelatonin labels sites of identical pharmacological characteristics in discrete areas of the chicken brain as those found in chicken brain membranes. Similarly, the affinity of the various MEL agonists and putative antagonists in the chicken brain OT (Table 3) correlates with the affinity of these compounds to inhibit $2-^{125} \mathrm{I}$-iodomelatonin binding in chicken retinal membranes $\left(25^{\circ} \mathrm{C} ; r=0.973\right.$; slope
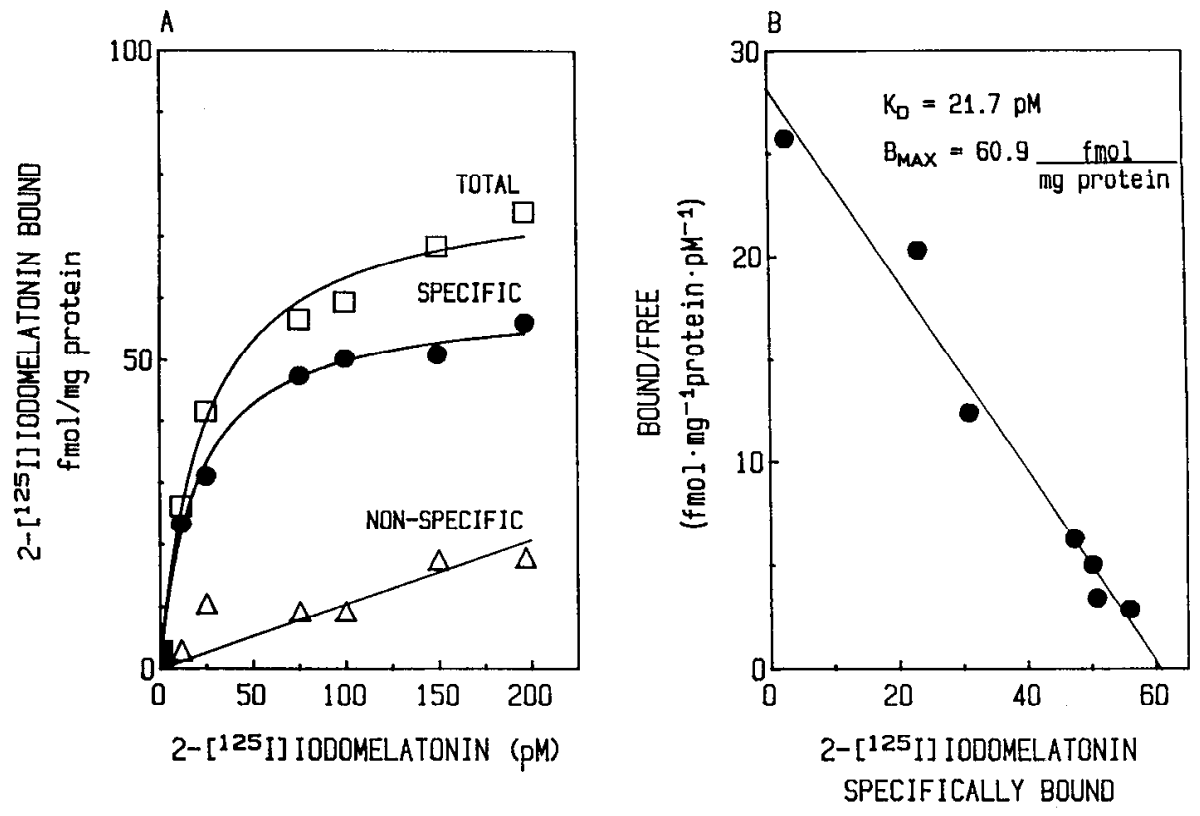

(fmol/mg protein)
Figure 4. A, Densitometric analysis of saturation binding in the OT of the chicken brain using quantitative autoradiography. Sequential coronal $20 \mu \mathrm{m}$ sections through the optic lobe were incubated with eight concentrations of ${ }^{2-125}$ I-iodomelatonin (0.1-200 pM). The specific binding (circles), defined as the difference between total (squares) and nonspecific (triangles), was saturable. $B$, Scatchard transformation of the saturation data. Values shown are from a representative experiment, with points representing the mean of triplicate determinations (three sections per slide). 
Figure 5. Pharmacological characterization of 2-125I-iodomelatonin binding in the OT using quantitative autoradiography. Coronal brain sections were incubated with 75 pM $2-{ }^{125}$ I-iodomelatonin in the presence of eight concentrations of one of the indicated drugs. Values shown are from a representative experiment, with points representing the mean of triplicate determinations (three sections per slide). A list of $K_{i}$ values (mean \pm SEM) for all drugs and areas examined are shown in Table 3.
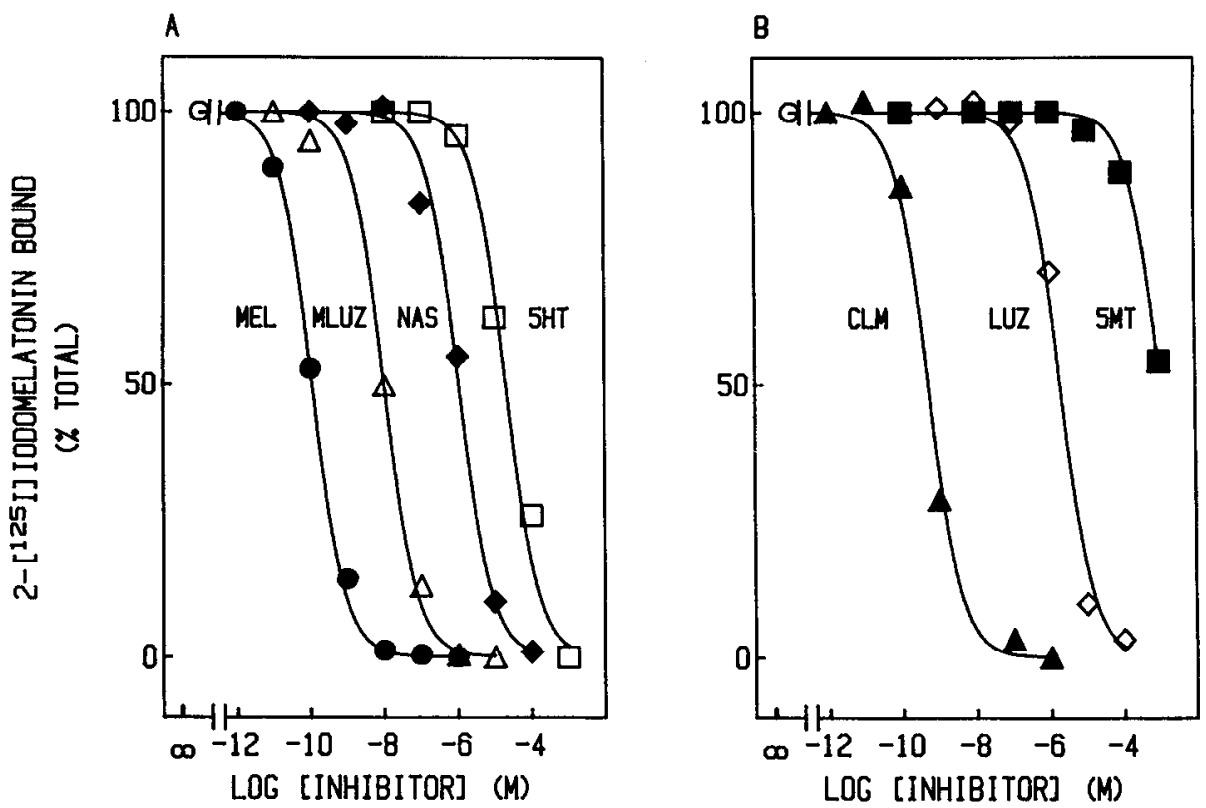

$=0.759 ; n=7$; Fig. $6 B)$ and in chicken brain membranes $\left(0^{\circ} \mathrm{C}\right.$; $r=0.946$; slope $=0.379 ; \mathrm{n}=7$; Fig. $6 C$ ). Finally, the pharmacological profile of the $2-^{-125}$ I-iodomelatonin binding sites in the OT correlates with either the potency of these compounds (i.e., MEL, CLM, NAS, 5-MT, MLUZ) to inhibit the calciumdependent release of ${ }^{3} \mathrm{H}$-dopamine or the affinity (i.e., LUZ) for the presynaptic MEL heteroreceptor of rabbit retina (Dubocovich, 1985, 1988b, 1990b) $(r=0.902$; slope $=0.506, n=6)$.

\section{Discussion}

The localization as well as the binding and pharmacological characteristics of 2-125 I-iodomelatonin binding sites in discrete areas of the adult chicken brain were determined using in vitro autoradiography. Binding sites were widely distributed throughout the entire brain, predominantly in areas associated with the visual system. This study confirms and extends previous qualitative autoradiographic studies of $2-^{125} \mathrm{I}$-iodomelatonin binding site localization in the brain of the 2-d-old chick (Stehle, 1990) and 12-d-old chick (Rivkees et al., 1989). Although most of the areas displaying specific 2-125I-iodomelatonin binding sites are the same in these two studies, there are several significant differences with the present results. First, the studies performed in chicks report binding in several auditory areas, including FL, nucleus ovoidalis, and the dorsolateral mesencephalic nucleus. We found specific 2 - $^{125}$ I-iodomelatonin binding only in FL in the adult chicken. Second, we did not find binding in the area ventralis of Tsai, an area reported to contain binding sites in the 12-d-old chick (Rivkees et al., 1989). Finally, we report a more extensive distribution of 2-125I-iodomelatonin binding sites in the adult chicken brain. Areas of chicken brain showing spccific binding of 2-125I-iodomelatonin in this study that have not been reported in previous studies include the following: mesencephalic sites-OMN, nIV, BCS; diencephalic sites-PT, SP, PST, TT, TRO, OC, HL, HY, GLDP; telencephalic structuresNC, NI, P, PO, LFB, HV, and CDL. These differences in the distribution of 2-125I-iodomelatonin binding between chicken

\begin{tabular}{|c|c|c|c|}
\hline Brain area & $n$ & $K_{D}(\mathrm{pM})$ & $B_{\max }(\mathrm{fmol} / \mathrm{mg}$ protein $)$ \\
\hline \multicolumn{4}{|l|}{ Mesencephalic areas } \\
\hline Optic tectum $(\mathrm{OT})$ & 8 & $43.49 \pm 9.18$ & $57.64 \pm 2.10$ \\
\hline Edinger-Westphal nucleus (EW) & 6 & $44.62 \pm 9.19$ & $41.08 \pm 3.25$ \\
\hline Oculomotor nucleus (OM) & 6 & $47.72 \pm 12.78$ & $33.54 \pm 5.74$ \\
\hline \multicolumn{4}{|l|}{ Diencephalic areas } \\
\hline Nucleus rotundus (R) & 6 & $44.69 \pm 10.14$ & $42.02 \pm 6.61$ \\
\hline Ventral supraoptic decussation (DSV) & 6 & $33.29 \pm 2.11$ & $39.82 \pm 4.28$ \\
\hline Ventrolateral geniculate nuclei (GLV) & 6 & $35.51 \pm 3.87$ & $35.58 \pm 3.39$ \\
\hline \multicolumn{4}{|l|}{ Telencephalic areas } \\
\hline Neostriatum intermedium (NI) & 8 & $37.94 \pm 2.72$ & $36.69 \pm 2.85$ \\
\hline Ectostriatum (E) & 8 & $45.37 \pm 6.94$ & $30.83 \pm 3.42$ \\
\hline
\end{tabular}

$K_{D}$ and $B_{\max }$ values shown represent the mean \pm SEM of independent determinations performed in triplicate (three sections per slide). Concentrations of $2-{ }^{125}$ I-iodomelatonin ranged from 0.1 pM to $1 \mathrm{nM}$. 

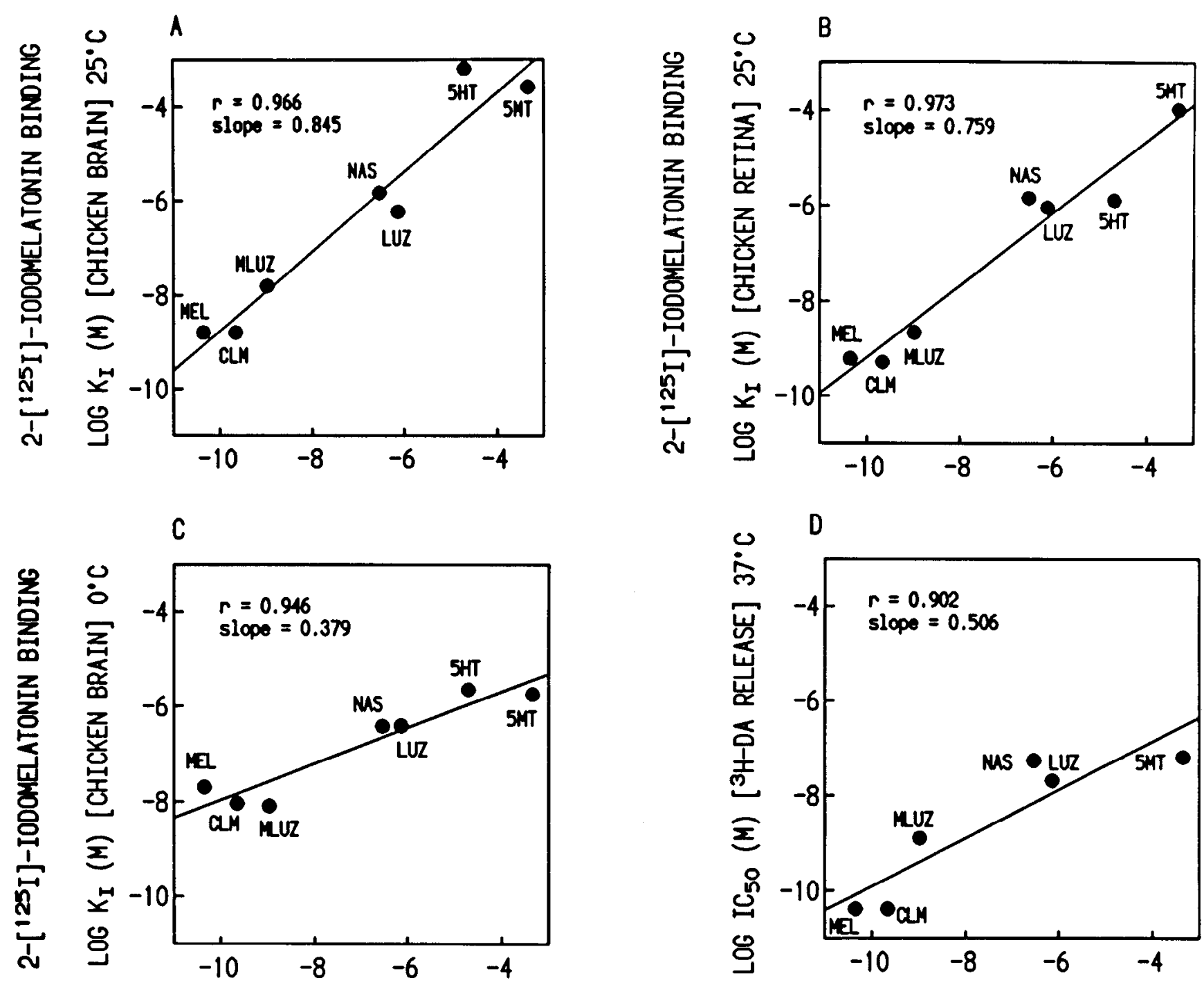

\section{LOG KI (M) [OPTIC TECTUM]}

\section{2-[125I]-IODOMELATONIN BINDING}

Figure 6. Correlation between the affinities ( $K_{i}$ values) of compounds for $2-^{125}$-iodomelatonin binding sites in the chicken OT using autoradiography and the affinities of compounds to inhibit $2{ }^{125}$ I-iodomelatonin binding in chicken brain membranes $\left(25^{\circ} \mathrm{C} ; A\right)$, chicken retinal membranes $\left(25^{\circ} \mathrm{C}\right.$; $B$ ), and chicken brain membranes $\left(0^{\circ} \mathrm{C} ; C\right)$ and to affect ${ }^{3} \mathrm{H}$-dopamine release from rabbit retina $(D) . K_{i}$ values for chicken brain $\left(0^{\circ} \mathrm{C}\right)$ were obtained from Dubocovich et al. (1989); for chicken brain $\left(25^{\circ} \mathrm{C}\right)$, from Chung and Dubocovich (unpublished observations); for chicken retinal membranes, from Dubocovich and Takahashi (1987), Dubocovich (1990b), and M. L. Dubocovich (unpublished observations). IC $\mathrm{C}_{50}$ values for the inhibition of ${ }^{3} \mathrm{H}$-dopamine release for various indoles (MEL, CLM, NAS, 5-MT, 5-HT) and the $K_{b}$ (dissociation constant) value for LUZ were obtained from Dubocovich $(1985,1988 \mathrm{~b}, 1990 \mathrm{~b})$. Linear regression of a logarithmic transformation of the data yielded the indicated slopes and correlation coefficients.

and chick brain may represent developmental changes or may be attributed to subtle differences in species and/or experimental conditions.

$2-{ }^{125}$ I-Iodomelatonin binding in the area referred to as the DSV (Fig. 2) appears to encompass other areas in addition to the DSV as shown in the atlas of Kuenzel and Masson (1989) (W. Kuenzel, personal communication). In this study, specific 2-125I-iodomelatonin binding in the DSV includes the nucleus of the supraoptic decussation, which is analogous to the visual SCN (vSCN) described in several studies (Meier, 1973; Gamlin et al., 1982; Cassone and Moore, 1987; Rivkees et al., 1989) and may also include the medial SCN (Hartwig, 1974; Kuenzel and Masson, 1989). Thus, this entire area displaying $2-{ }^{125} \mathrm{I}-$ iodomelatonin binding in this study may actually represent a suprachiasmatic region. Although the functional role of the area referred to as the DSV has not been established, one of its components (i.e., the vSCN) is thought to be analogous to the mammalian SCN, which also contains MEL receptor sites (Laitinen and Saavedra, 1990) and may be involved in mediating the effect of MEL on circadian rhythms.

More extensive analysis of selected brain regions showed the binding of $2-{ }^{125} \mathrm{I}$-iodomelatonin to be saturable, reversible, and to a single high-affinity site. The $K_{D}$ values for the MEL binding site in the chicken brain ( $33-48 \mathrm{pm}$ ) are in the range of previously 


\begin{tabular}{|c|c|c|c|c|c|c|c|}
\hline Brain area & MEL (pм) & CLM (рм) & MLUZ (nM) & NAS (nM) & LUZ (nM) & 5 -HT $(\mu \mathrm{M})$ & 5-MT $(\mu \mathrm{M})$ \\
\hline \multicolumn{8}{|l|}{ Mesencephalic areas } \\
\hline $\begin{array}{l}\text { Optic tectum } \\
\text { (OT) }\end{array}$ & $\begin{array}{c}44.92 \pm 4.21 \\
(8)\end{array}$ & $\begin{array}{c}215.52 \pm 7.24 \\
(4)\end{array}$ & $\begin{array}{c}1.04 \pm 0.04 \\
(4)\end{array}$ & $\begin{array}{c}294.69 \pm 33.48 \\
(4)\end{array}$ & $\begin{array}{c}745.15 \pm 129.45 \\
\text { (4) }\end{array}$ & $\begin{array}{c}19.97 \pm 3.38 \\
(6)\end{array}$ & $\begin{array}{c}459.69 \pm 39.18 \\
\text { (4) }\end{array}$ \\
\hline $\begin{array}{l}\text { Edinger-Westphal } \\
\text { nucleus (EW) }\end{array}$ & $\begin{array}{c}71.27 \pm 6.51 \\
(6)\end{array}$ & $\begin{array}{c}205.94 \pm 5.72 \\
(4)\end{array}$ & $\begin{array}{c}2.40 \pm 1.26 \\
(4)\end{array}$ & $\begin{array}{c}256.94 \pm 63.61 \\
(4)\end{array}$ & $\begin{array}{c}616.26 \pm 70.16 \\
(4)\end{array}$ & $\begin{array}{c}16.35 \pm 3.73 \\
(4)\end{array}$ & $\begin{array}{c}748.02 \pm 10.79 \\
(4)\end{array}$ \\
\hline \multicolumn{8}{|l|}{ Diencephalic areas } \\
\hline $\begin{array}{l}\text { Nucleus rotundus } \\
\text { (R) }\end{array}$ & $\begin{array}{c}51.76 \pm 7.71 \\
(6)\end{array}$ & $\begin{array}{c}312.90 \pm 19.83 \\
(4)\end{array}$ & $\begin{array}{c}2.59 \pm 0.61 \\
(4)\end{array}$ & $\begin{array}{c}244.30 \pm 53.91 \\
(4)\end{array}$ & $\begin{array}{c}902.33 \pm 139.48 \\
(4)\end{array}$ & $\begin{array}{c}16.65 \pm 3.98 \\
(4)\end{array}$ & $\begin{array}{c}462.82 \pm 66.33 \\
(6)\end{array}$ \\
\hline $\begin{array}{l}\text { Ventral supraoptic } \\
\text { decussation(DSV) }\end{array}$ & $\begin{array}{c}55.36 \pm 7.51 \\
(6)\end{array}$ & $\begin{array}{c}212.54 \pm 15.42 \\
\text { (4) }\end{array}$ & $\begin{array}{c}1.29 \pm 0.42 \\
(4)\end{array}$ & $\begin{array}{c}241.03 \pm 32.11 \\
(4)\end{array}$ & $\begin{array}{c}639.01 \pm 124.58 \\
(4)\end{array}$ & $\begin{array}{c}18.60 \pm 1.61 \\
(4)\end{array}$ & $\begin{array}{c}640.64 \pm 186.88 \\
(4)\end{array}$ \\
\hline $\begin{array}{l}\text { Ventrolateral } \\
\text { geniculate } \\
\text { nucleus (GLV) }\end{array}$ & $\begin{array}{c}58.61 \pm 9.14 \\
(6)\end{array}$ & $\begin{array}{c}239.38 \pm 14.68 \\
(4)\end{array}$ & $\begin{array}{c}2.47 \pm 0.13 \\
(4)\end{array}$ & $\begin{array}{c}237.76 \pm 11.45 \\
(4)\end{array}$ & $\begin{array}{c}774.65 \pm 85.10 \\
(4)\end{array}$ & $\begin{array}{c}19.98 \pm 0.53 \\
(4)\end{array}$ & $\begin{array}{c}608.08 \pm 174.88 \\
(4)\end{array}$ \\
\hline \multicolumn{8}{|l|}{ Telencephalic areas } \\
\hline $\begin{array}{l}\text { Neostriatum inter- } \\
\text { medium (NI) }\end{array}$ & $\begin{array}{c}37.14 \pm 1.67 \\
(8)\end{array}$ & $\begin{array}{c}210.22 \pm 7.16 \\
(4)\end{array}$ & $\begin{array}{c}2.25 \pm 0.23 \\
(6)\end{array}$ & $\begin{array}{c}266.77 \pm 15.76 \\
(4)\end{array}$ & $\begin{array}{c}843.06 \pm 33.93 \\
(4)\end{array}$ & $\begin{array}{c}17.56 \pm 3.41 \\
(4)\end{array}$ & $\begin{array}{c}655.72 \pm 66.04 \\
(4)\end{array}$ \\
\hline $\begin{array}{l}\text { Ectostriatum } \\
\text { (E) }\end{array}$ & $\begin{array}{c}76.06 \pm 18.40 \\
(4)\end{array}$ & $\begin{array}{c}304.74 \pm 11.88 \\
(4)\end{array}$ & $\begin{array}{c}3.33 \pm 0.27 \\
(4)\end{array}$ & $341.39 \pm 13.85$ & $\begin{array}{c}815.40 \pm 76.51 \\
(4)\end{array}$ & $\begin{array}{c}23.65 \pm 8.57 \\
(4)\end{array}$ & $\begin{array}{c}685.96 \pm 38.48 \\
(4)\end{array}$ \\
\hline
\end{tabular}

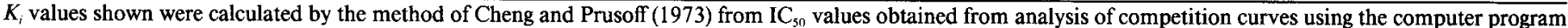

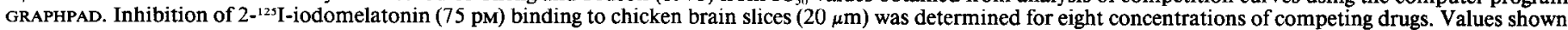

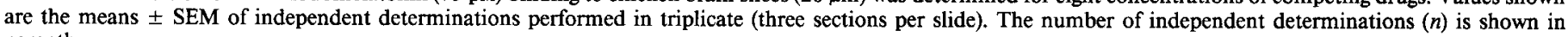
parentheses.

reported affinity constants obtained for the MEL binding site using autoradiography in the rat area postrema and SCN (45.9 and 52.8 pM, respectively; Laitinen and Saavedra, 1990; Laitinen et al., 1990), rat ME (43 pM; Weaver et al., 1989), and mouse thalamic PVN (77.44 pM; Fang et al., 1990). In homogenates of the chicken OT and whole brain, $K_{D}$ values were 87.2 and 60 pм, respectively (Rivkees et al., 1989; Stehle, 1990). Dubocovich et al. $(1989,1990)$ reported $K_{D}$ values of 344,99 , and $56 \mathrm{pm}$ for chicken brain membranes incubated at $0^{\circ} \mathrm{C}, 25^{\circ} \mathrm{C}$, and $37^{\circ} \mathrm{C}$, respectively. Our data indicate binding to only one site, which is in agreement with previous studies in chicken brain membranes (Dubocovich et al., 1989; Rivkees et al., 1989; Stehle, 1990); however, it is not possible to exclude totally the presence of a lower-affinity site. Laitinen and Saavedra (1990) reported the presence of a low-affinity binding site in the rat $\operatorname{SCN}\left(K_{D}=761 \mathrm{pM}\right)$ when wash durations were decreased to 2 min. Therefore, the assay conditions used in the present study $\left(25^{\circ} \mathrm{C}\right.$ and $15 \mathrm{~min}$ wash) may have resulted in preferential examination of high-affinity sites.

The $B_{\max }$ values (31-58 $\mathrm{fmol} / \mathrm{mg}$ protein) obtained in the regions examined are in the range previously reported using membrane preparations in chicken whole brain: $56 \mathrm{fmol} / \mathrm{mg}$ protein (Dubocovich et al., 1990) and $37.8 \mathrm{fmol} / \mathrm{mg}$ protein (Rivkees et al., 1989).

The pharmacological order of affinities of the indole compounds for $2-^{125}$ I-iodomelatonin binding in this study agrees with previous reports in which MEL binding sites were characterized in chicken brain and in chicken and rabbit retinal homogenates (Dubocovich and Takahashi, 1987; Dubocovich et al., 1989; Dubocovich, 1990a). MEL and MEL analogs (i.e., CLM and MLUZ) possessing a methoxy group on carbon 5 and an acetamido group on carbon 3 of the indole nucleus were the most potent inhibitors of $2-{ }^{125} \mathrm{I}$-iodomelatonin binding. NAS is significantly less potent than MEL at inhibiting the binding of $2-{ }^{125}$ I-iodomelatonin, unlike in the hamster brain, where the two compounds are equipotent (Dubocovich and Takahashi, 1987; Dubocovich, 1988a; Duncan et al., 1988). Removal of the $N$-acetyl group from the MEL molecule (e.g., 5-MT) caused a dramatic reduction in the potency to inhibit $2-{ }^{125} \mathrm{I}$-iodomelatonin $(459-748 \mu \mathrm{M})$ in these chicken brain areas. This pharmacological order of affinities suggests that the 5-methoxy group is important for binding, as shown by the low affinity of LUZ for 2-125I-iodomelatonin when compared with MLUZ.

The pharmacological affinities of the various indoles on $2-{ }^{125} \mathrm{I}-$ iodomelatonin binding determined in discrete areas of chicken brain are very similar to that of the ML-1 MEL receptor found in brain and retina (Dubocovich, 1985, 1988a,b, 1990a,b; Dubocovich and Takahashi, 1987; Dubocovich et al., 1989, 1990). In support of these results, we have shown a correlation between the $K_{l}$ values obtained in this study and the $K_{l}$ values to inhibit $2-{ }^{125} \mathrm{I}$-iodomelatonin binding in chicken brain and retinal membranes (Fig. 6A,B). Correlations performed between the affinity constants in the OT versus affinities in chicken brain and retinal membranes at $25^{\circ} \mathrm{C}$ yielded similar slopes (slopes $=0.845$ and 0.759 , respectively). In contrast, correlations based on binding studies performed at $0^{\circ} \mathrm{C}$ in chicken brain membranes resulted in a flattening of the slope (slopc $=0.379$; Fig. $6 \mathrm{C}$ ). This may reflect a lower affinity of the radioligand for the MEL binding site at lower temperatures (Dubocovich et al., 1990), possibly as a result of a decoupling of the receptor from a G-protein. Finally, the highly significant correlation found between the affinity of indoles to inhibit 2-125 I-iodomelatonin binding in tectum, and the potency of the MEL agonists or the affinity of LUZ for the MEL presynaptic receptor to inhibit ${ }^{3} \mathrm{H}$-dopamine release from retina, suggest that the MEL binding sites found in discrete areas of chicken brain are very likely functional MEL receptors.

The density values obtained for the various areas in the chicken brain demonstrate the heterogeneous distribution of $2-{ }^{125} \mathrm{I}-$ iodomelatonin binding sites throughout the chicken brain. A 
majority of the areas where binding was found are involved in the receiving or mediation of visual information. Ehrlich and Mark (1984) reported dense visual projections in the lateral and dorsolateral anterior thalamic nuclei, ventrolateral and dorsolateral geniculate nuclei (GLV and GLDP), BOR, and most extensively within the OT. Other areas showing MEL binding sites (see Table 1), although not direct recipients of retinal projections, serve as relay and terminal areas of the visual projection systems. For example, the two major sources of visual input from the thalamus to the telencephalon in bird are the thalamofugal (retino-thalamo-hyperstriatal projection) and tectofugal (retino-tecto-rotundo-ectostriatal projections) systems (Cohen and Karten, 1974). Other areas that exhibit 2-125Iiodomelatonin binding receive significant input from retinorecipient areas; for example, the $\mathrm{R}$ is a major site of projections from the OT, and the isthmi, pretectal, and subpretectal nuclei also receive tectal afferents. Furthermore, 2-125 I-iodomelatonin binding sites are also found in areas such as the EW, which are involved in eyeball movements, pupillary contraction, and accommodation (Pearson, 1972). Recently, a retina-SCN-medial EW pathway in the pigeon has been described, which mediates increases in choroidal blood flow in the eye in response to retinal illumination (Fitzgerald and Reiner, 1990). This distribution of MEL receptors suggests that MEL may play a role in influencing various aspects of the avian visual system.

In conclusion, quantitative autoradiographic analysis of 2-125 Iiodomelatonin binding sites in discrete areas of the chicken brain strongly suggests that these sites are identical to the ML-1 sites found in chicken brain and retinal membranes. The binding and pharmacological characteristics of these MEL binding sites show distinct differences from the sites described previously in hamster brain membranes (Duncan et al., 1988). Furthermore, the high correlations between the affinities of MEL and related indoles in these studies with the potency of these compounds to mediate a functional response in the rabbit retina suggest that in the chicken brain these receptor sites may mediate functional responses regulated by MEL.

\section{References}

Barchas J, DaCosta F, Spector S (1967) Acute pharmacology of melatonin. Nature 214:919-920.

Cassone VM, Menaker M (1984) Is the avian circadian system a neuroendocrine loop? J Exp Zool 232:539-549.

Cassone VM, Moore RY (1987) Retinohypothalamic projection and suprachiasmatic nucleus of the house sparrow, Passer domesticus. $\mathrm{J}$ Comp Neurol 266:171-182.

Cassone VM, Lane RF, Menaker M (1986) Melatonin-induced increases in serotonin concentrations in specific regions of the chick brain. Neuroendocrinology 42:38-43.

Cheng YC, Prusoff WH (1973) Relationship between the inhibition constant and the correlation of inhibitor which causes $50 \%$ inhibition $\left(\mathrm{IC}_{50}\right)$ of an enzymatic reaction. Biochem Pharmacol 22:3099-3108.

Cohen DH, Karten HJ (1974) The structure and organization of the avian brain: an overview. In: Birds, brain and behavior (Goodman IJ, Schein MW, eds), pp 45-50. New York: Academic.

Dubocovich ML (1983) Melatonin is a potent modulator of dopamine release in the retina. Nature 306:782-784.

Dubocovich ML (1985) Characterization of a retinal melatonin receptor. J Pharmacol Exp Ther 234:395-401.

Dubocovich ML (1988a) Pharmacology and function of melatonin receptors. FASEB J 2:2765-2773.

Dubocovich ML (1988b) Luzindole (N-0774): a novel melatonin receptor antagonist. J Pharmacol Exp Ther 246:902-910.

Dubocovich ML (1990a) Pharmacology and function of melatonin receptors in the mammalian central nervous system. In: Serotonin: actions, receptors, pathophysiology (Mylecharane EJ, Angus JA, de la Lande ES, Humphrey PA, eds), pp 265-273. New York: Macmillan.
Dubocovich ML (1990b) Structure activity relationships: pharmacology and function of melatonin receptors. In: Trends in drug research (Claaseen V, ed), pp 23-36. New York: Elsevier.

Dubocovich MI, Takahashi JS (1987) Use of 2-[125I]-iodomelatonin to characterize melatonin binding sites in chicken retina. Proc Natl Acad Sci USA 84:3916-3920.

Dubocovich ML, Shankar G, Mickel M (1989) 2-[125I]-Iodomelatonin labels sites with identical pharmacological characteristics in chicken brain and chicken retina. Eur J Pharmacol 162:289-299.

Dubocovich ML, Siuciak JA, Krause DN (1990) Localization of high affinity melatonin receptor sites in chick brain: effect of temperature and guanine nucleotides. Eur J Pharmacol 183:2180.

Duncan MJ, Takahashi JS, Dubocovich ML (1988) 2-[125I]-Iodomelatonin binding sites in hamster brain membranes: pharmacological characteristics and regional distribution. Endocrinology 122:18251833.

Duncan MJ, Takahashi JS, Dubocovich ML (1989) Characterization and localization of 2-[125I]-iodomelatonin binding sites in Djungarian hamster brain. Endocrinology 125:1011-1017.

Ebihara S, Kawamura H (1981) The role of the pineal organ and the suprachiasmatic nuclcus in the control of circadian locomotor rhythms in the java sparrow. J Comp Physiol 141:207-214.

Ebihara S, Uchiyama K, Oshima I (1984) Circadian organization in the pigeon, Columba livia: the role of the pineal organ and the eye. J Comp Physiol 154:59-69.

Ehrlich D, Mark R (1984) An atlas of the primary visual projections in the brain of the chick Gallus gallus. J Comp Neurol 223:592-610.

Fang JM, Siuciak JA, Krause DN, Dubocovich ML (1990) Localization and characterization of melatonin binding sites in $\mathrm{C} 3 \mathrm{H} / \mathrm{HeN}$ and C57/BL6J mice. Pharmacologist 32:144.

Fitzgerald MEC, Reiner A (1990) Light-mediated reflexive control of choroidal blood flow in the pigeon eye. Soc Neurosci Abstr 16:1077.

Gamlin PDR, Reiner A, Karten HJ (1982) Substance P-containing neurons of the avian suprachiasmatic nucleus project directly to the nucleus of Edinger-Westphal. Proc Natl Acad Sci USA 79:38913895 .

Gaston S, Menaker M (1968) Pineal function: the biological clock in the sparrow. Science 160:1125-1126.

Hartwig HG (1974) Electron microscopic evidence for a retinohypothalamic projection to the suprachiasmatic nucleus of Passer domesticus. Cell Tissue Res 153:89-99.

Johnson PA, van Tiehoven A (1984) Plasma luteinizing hormone levels throughout development and relative to ovulation in pinealectomized hens. Gen Comp Endocrinol 54:450-456.

Kuenzel WJ, Masson M (1989) A stereotaxic atlas of the brain of the chick (Gallus domesticus). Baltimore: Johns Hopkins UP.

Laitinen JT, Saavedra JM (1990) Characterization of melatonin receptors in the rat suprachiasmatic nuclei: modulation of affinity with cations and guanine nucleotides. Endocrinology 126:2110-2115.

Laitinen JT, Flugge G, Saavedra JM (1990) Characterization of melatonin receptors in the rat area postrema: modulation of affinity with cations and guanine nucleotides. Neuroendocrinology 51:619-624.

Liou SS, Cogburn LA, Biellier HV (1987) Photoperiodic regulation of plasma melatonin levels in the laying chicken. Gen Comp Endocrinol 67:221-226.

Meier R (1973) Autoradiographic evidence for a direct retinohypothalamic projection in the avian brain. Brain Res 53:417-421.

Menaker M, Zimmermann NH (1976) Role of the pineal in the circadian system of birds. Am Zool 16:45-55.

Miller J, Zahniser N (1987) The use of ${ }^{14} \mathrm{C}$ labeled standards for the calibration of ${ }^{125} \mathrm{I}$ labeled ligands in quantitative autoradiography. Neurosci Lett 81:345-350.

Ohta M, Kadota C, Konishi H (1989) A role of melatonin in the initial stage of photoperiodism in the Japanese quail. Biol Reproduction 40: 935-941.

Oshima I, Yamada H, Goto M, Sato K, Ebihara S (1989) Pineal and retinal melatonin is involved in the control of circadian locomotor activity and body temperature rhythms in the pigeon. J Comp Physiol 166:217-226.

Pang SF, Ralph CL, Reilly DP (1974) Melatonin in the chicken brain: its origin, diurnal variation and regional distribution. Gen Comp Endocrinol 22:499-506.

Pang SF, Brown GM, Grota LJ, Chambers JW, Rodman RL (1977) Determinations of $\mathrm{N}$-acetylserotonin and melatonin activities in the pineal gland, retina, Harderian gland, brain and serum of rats and chickens. Neuroendocrinology 23:1-13. 
Pang SF, Chow PH, Wong TM, Tso EC (1983) Diurnal variations of melatonin and $N$-acetylserotonin in the tissues of quails, pigeons and chickens. Gen Comp Endocrinol 51:1-7.

Pearson R (1972) The avian brain, pp 12-13. New York: Academic. Pickering DS, Niles LP (1990) Pharmacological characterization of melatonin binding sites in Syrian hamster hypothalamus. Eur J Pharmacol 175:71-77.

Ralph CL (1981) Melatonin production in extrapineal tissues. In: Melatonin: current status and perspectives (Birau N, Schloot W, eds) pp 35-45. Oxford: Pergamon.

Rivkees S, Cassone VM, Weaver DR, Reppert SM (1989) Melatonin receptors in chick brain: characterization and localization. Endocrinology 125:363-368.

Simpson SM, Follet BK (1981) Pineal and hypothalamic pacemakers: their role in regulating circadian rhythmicity in Japanese quail. $\mathrm{J}$ Comp Physiol 144:381-389.

Siuciak JA, Dubocovich ML (1989) Localization of melatonin binding sites in the chicken brain. Soc Neurosci Abstr 15:587.

Siuciak JA, Fang JM, Dubocovich ML (1990) Autoradiographic localization of 2-[125I]-iodomelatonin binding sites in the brains of $\mathrm{C} 3 \mathrm{H} /$ $\mathrm{HeN}$ and C57BL/6J strains of mice. Eur J Pharmacol 280:387-390.
Stehle J (1990) Melatonin binding sites in brain of the 2-day old chicken: an autoradiographic localization. J Neural Transm 81:8389.

Turek FW, McMillan JP, Menaker M (1976) Melatonin: effects on the circadian locomotor rhythms of sparrows. Science 194:1441-1443.

Vakkuri O, Leppaluoto J, Vuolteenano O (1984) Development and validation of a melatonin radioimmunoassay using radioiodinated melatonin as a tracer. Acta Endocrinol 106:152-157.

Vakkuri O, Rintamaki H, Leppaluoto J (1985) Presence of immunoreactive melatonin in different tissues of the pigeon. Gen Comp Endocrinol 58:69-75.

Vanecek J, Pavlek A, Illnerova H (1987) Hypothalamic melatonin receptor sites revealed by autoradiography. Brain Res 435:359-362.

Weaver D, Rivkees SA, Reppert SM (1989) Localization and characterization of melatonin receptors in rodent brain by in vitro autoradiography. J Neurosci 9:2581-2586.

Yamada H, Oshima I, Sato K, Ebihara S (1988) Loss of the circadian rhythm of locomotor activity, food intake and plasma melatonin concentration mediated by constant bright light in the pigeon. J Comp Physiol A 163:459-463. 